TITLE:

\title{
ON THE SO-CALLED "UMI-UTIWA," A PECULIAR FLABELLATE GORGONACEAN, WITH NOTES ON A SYLLIDEAN POLYCHAETE COMMENSAL
}

\author{
$\operatorname{AUTHOR}(\mathrm{S})$ : \\ Utinomi, Huzio
}

\section{CITATION:}

Utinomi, Huzio. ON THE SO-CALLED "UMI-UTIWA," A PECULIAR FLABELLATE GORGONACEAN, WITH NOTES ON A SYLLIDEAN POLYCHAETE COMMENSAL.

PUBLICATIONS OF THE SETO MARINE BIOLOGICAL LABORATORY 1956, 5(2): 243-250

\section{ISSUE DATE:}

1956-06-30

URL:

http://hdl.handle.net/2433/174554

RIGHT: 


\title{
ON THE SO-CALLED “UMI-UTIWA," A PECULIAR FLABELLATE GORGONACEAN, WITH NOTES ON A SYLLIDEAN POL YCHAETE COMMENSAL ${ }^{1}$
}

\author{
HUZIO UTINOMI \\ Seto Marine Biological Laboratory, Sirahama
}

With Plate XXVII and 2 Text-figures

Along the Pacific coast of southern Japan, a large gorgonacean colony of flabellate branching, which is usually known as "Umi-utiwa", 2) is occasionally found, as stranded on the beach or caught by fishermen's nets. The stranded colony is usually almost denuded without bark while being cleaned ashore, so that anyone who happened to see it cannot decide to which kind of the Gorgonacea it should be referred.

The axis of the colony is very firm in texture, dark brown to black in color and flabellate with dense anastomoses in outline. A similar, possibly the same, gorgonacean coral is listed or figured under the name "Rhipidogorgia" in many representative textbooks of zoology published in Japan. ${ }^{3}$ This is evidently an erroneous identification due to the superficial resemblance in the flabellate growth form, since the gorgonacean named as such (exactly Gorgonia flabellum Linnaeus, syn. Rhipidogorgia flabellum) is a separate species living only on the Atlantic coast of North America and in the West Indies (BAYER, 1951).

While examining the gorgonacean materials, a number of living and dead colonies referable to this so-called "Umi-utiwa" from various localities came to my hand. On examination on the spiculation and other structures, I came to a conclusion that they should be referred to a Muriceid holaxonian, Anthogorgia bocki Aurivillius (1931), originally recorded from the Bonin Islands.

Moreover, I found that the living colonies of this species are frequently infested with a polychaete commensal belonging to the syllid genus Haplosyllis.

1) Contributions from the Seto Marine Biological Laboratory, No. 280.

2) "Umi-utiwa" or "Umi-uchiwa" means a sea-fan in Japanese. A similar name is given also for a marine brown alga, Padina arborescens Holmes.

3) For example, see I. IJIMA's "A manual of zoology (Dôbutugaku Teiyô)" (1918), p. 333, fig. 386; N. Yatsu's "Classification table of animals (Dôbutu Bunruihyô)" (1920, 1923), p. 41 ; IWANAMI's "Zoological dictionary (Dôbutugaku Ziten)" (1935), p. 908.

Publ. Seto Mar. Biol. Lab., V (2), 1956. (Article 14) 


\section{Descriptions of Anthogorgia bocki AURIVILlIUS}

(Text-fig. 1 and Pl. XXVII)

\section{Specimens from Seto and Kii-ôsima, Wakayama Pref., Honsyû.}

In the Museum of our Laboratory, there are at present four large and small colonies. Among them an incomplete colony from Kii-ôsima (Pl. XXVII, Fig. 3), about $24 \mathrm{~cm}$ long, obtained in 1940, and a complete colony from Seto, about $35 \mathrm{~cm}$ long and $23 \mathrm{~cm}$ wide, obtained in January 1955 , are wholly covered with a thin bark. Of the remaining two from Seto, which are entirely naked and dry, the largest one obtained on September 6,1944 (Pl. XXVII, Fig. 2) is about $60 \mathrm{~cm}$ in height and 40 $\mathrm{cm}$ in width. Its basal attachment is now lacking, but the main stem at the base measures $11 \times 8 \mathrm{~mm}$ in diameter.

Entire colony flabellate, branched in one plane, with profuse anastomoses of both large and small branches. Branching sinuous and irregular. Larger branches flattened at right angles to the plane of branching, whereas small twigs are round in cross section, less than $1 \mathrm{~mm}$ in diameter, arising perpendicularly from the flattened lateral sides of main stem and larger branches. Axis purely horny, stout, dark brown to black, and marked by longitudinal grooves; but at end-twigs it is sometimes naked, leaving only its central chord which is about $0.35-0.45 \mathrm{~mm}$ in diameter, soft, flexible, chambered internally and colored olive or light brown (Fig. $1 \mathrm{~g}$ ).

Polyps occur on all sides of the colony, relatively sparsely on larger branches, becoming more densely and more numerous toward smaller branches. Polyps short tubular, roundly tipped, with 8-rayed orifice at its center; they are usually about $1 \mathrm{~mm}$ in diameter and $1-1.8 \mathrm{~mm}$ in height in retracted condition. Verrucal walls densely covered with fusiform, strongly warted, about $0.3-0.4 \mathrm{~mm}$ long spicules arranged transversely; at their tip similar spindles formed of eight points of 3 to 5 pairs, each clustered in a triangle, which close over the tentacles in retraction, forming together an operculum. Tentacles, folding within the orifice, bear about $0.18-0.28 \mathrm{~mm}$ long warty spicules longitudinally placed and about $0.05-0.1 \mathrm{~mm}$ long rodlike pinnular spicules laterally.

Bark moderately thin, easily rubbed off, covered with layer of large, bluntly-ended warty spindles as long as $1.3 \mathrm{~mm}$; deeper layer of generally smaller spindles or rods with bifurcate ends between them. Color of bark and all sclerites orangish in life, though faded in spirit.

\section{Spicule measurements-}

Opercular (point) spindles: $0.3 \times 0.09 \mathrm{~mm}, 0.35 \times 0.09 \mathrm{~mm}, 0.4 \times 0.1 \mathrm{~mm}$.

Outer stem spindles : $0.35 \times 0.09 \mathrm{~mm}, 0.45 \times 0.12 \mathrm{~mm}, 0.5 \times 0.14 \mathrm{~mm}, 0.6 \times 0.16 \mathrm{~mm}$,

$$
0.8 \times 0.18 \mathrm{~mm}, 0.9 \times 0.29 \mathrm{~mm}, 1.1 \times 0.23 \mathrm{~mm}, 1.3 \times 0.35 \mathrm{~mm} \text {. }
$$

Smaller stem rods : $0.07 \times 0.035 \mathrm{~mm}, 0.09 \times 0.07 \mathrm{~mm}, 0.12 \times 0.04 \mathrm{~mm}, 0.18 \times 0.05 \mathrm{~mm}$.

2. Specimen from Tomioka, Kumamoto Pref., Kyûsyû.

In the Amakusa Marine Biological Station of Kyusyu University at Tomioka, a 
magnificent large colony (Pl. XXVII, Fig. 1) is preserved. Its total height is about $60 \mathrm{~cm}$ and maximum width is about $67 \mathrm{~cm}$, though lacking the base of attachment. It is wholly dry, but the branches are densely reticulate and the bark with polyps remained here and there, especially near the center of the somewhat hollowed upper surface of

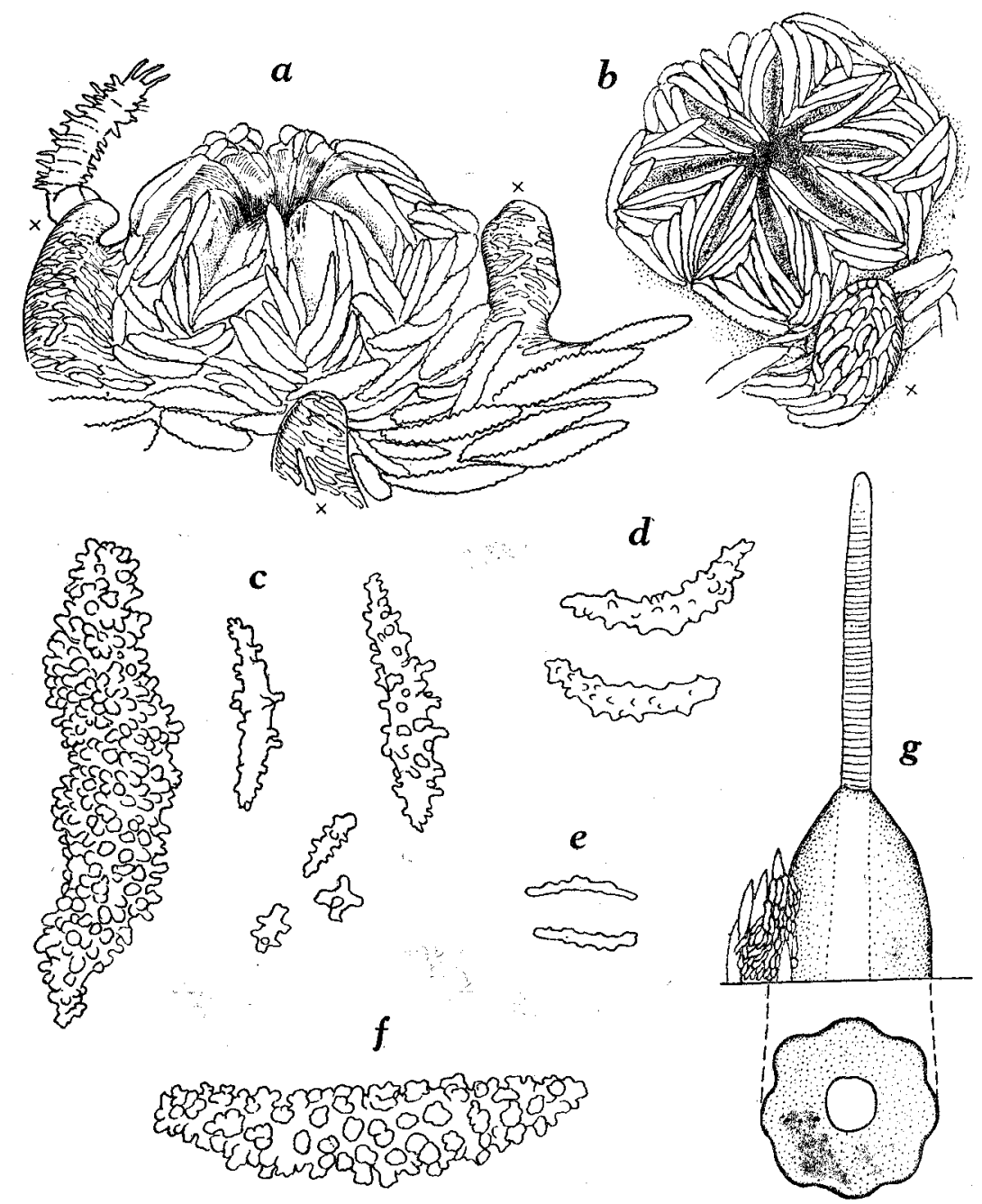

Fig. 1. Anthogorgia bocki AurivilluUs from Seto.

$a$, A retracted polyp, with three dwellings of commensal syllid around it (indicated by a cross mark $(x)$, viewed from side, $\times 35 ; b$, upper view of retracted polyp, with a dwelling of commensal syllid $(x)$ at base, $x 35 ; c$, stem spicules, of which the largest one from outer layer of bark and the remainder from the inner layer, $\times 150 ; d$, tentacle spicules, $\times 510 ; \ell$, pinnular spicules, $\times 510 ; f$, point spicule, $\times 510$; $g$, denuded end of twigs, showing a central chord terminally and layered spicular coverings on axis (above) and a cross-section of axis (below), somewhat diagrammatic. 
the flabellum, the outer edges being slightly bent upward. Small twigs ending freely occur densely on the upper surface and are all bent upward. Denuded axis is brownish black, smaller twigs dark brown, while the remained bark brownish white or colorless.

\section{Specimen from Inan coast, Ehime Pref., Sikoku.}

In the Biological Institute of Ehime University at Matuyama, there is also a large incomplete colony, probably referable to this species. The specimen is dry and entirely devoid of bark.

Remarks. Inasmuch as I have consulted, nine species have been described as belonging to the genus Anthogorgia: A. divaricata Verrill (1866), A. japonica Studer (1889), A. verrilli Thomson \& Henderson (1906), A. racemosa Thomson \& Simpson (1909), A. glomerata Thomson \& Simpson (1909), A. aurea Nutting (1910), A. grandiflora KüKEnThal (1924) (= A. verrilli NuTtTING, 1910), A. annectens Thomson \& Dean (1931) and $A$. bocki Aurivillius (1931). Most of these species have cylindrical polyps rising to a height of $3-4 \mathrm{~mm}$ and flabellate branches with or without anastomosis. The last-named bocki, to which I have referred the specimens here described, has not yet been recorded since the original report. But as inferred from this finding from various localities, this species may be common in the southern Japan.

The type specimen of $A$. bocki from Bonin Islands is, according to Aurivilluus, $19 \mathrm{~cm}$ long and $26 \mathrm{~cm}$ wide, with the basal portion of stem only $5 \mathrm{~mm}$ in diameter, and the anastomoses are occasional, but not dense. It is thus smaller and younger than those I have examined.

As regards the systematic position of the genus Anthogorgia VerRILl (1868, 1869), most of the former authors are right in placing it in the family Muriceidae Gray. Only exceptionally, Gordon (1926, p. 510, foot-note) and Aurivillius (1931) are of opinion that Anthogorgia (according to GoRDON, together with Boarella GRAY and Versluysia NutTING, and according to AURIviLlius, together with Eumuricea VerRILL) should be included in the family Acanthogorgiidae KüKenthal rather than in the Muriceidae.

Stiasny (1940) recorded A. japonica and A. grandiflora from Red Sea, both placing in the Muriceidae, but later (1943, p. $130 ; 1947$, p. 84) proposed to transfer A. bocki alone amongst the species of Anthogorgia to the genus Acalycigorgia in the Acanthogorgiidae, basing solely on the description of AuRIvilirus and partly accepting his first intention to refer to the same genus. Both authors' view cannot be supported for the specimens of Anthogorgia and Acalycigorgia at hand.

Although the separation of the family Acanthogorgiidae from the family Muriceidae is not entirely satisfactory, as criticized by Hickson (1930), the majority of the acanthogorgiids have very prominent, long, 'non-retractile' calyx whose spicules form generally 8 ridges in the longitudinal direction of the polyp, and do not form any collaret ring. The so-called 'operculum' which is usual in the muriceid corals is absent 
or indistinct. In the present $A$. bocki, however, as in other muriceids, the anthocodial part of polyps, where uppermost spicules of eight points form together the operculum, is more or less retractile into tubular verrucae, though the points of the operculum are not entirely withdrawn into it. Although there is no spiculeless neck zone below the operculum, the retractibility of the anthocodia is aided by the transverse arrangement of verrucal spicules in the lower part of polyps. In these respects, Anthogorgia is most closely related to the genus Calicogorgia (e.g. C. granulosa Kükenthal \& GoRZAwskY) amongst the Muriceidae. In the latter genus, however, the point spicules are not so regularly arranged en chevron and the verrucal spicules are more irregularly distributed.

\section{Descriptions of a polychaete commensal Haplosyllis anthogorgicola sp. nov.}

(Text-fig. 2)

As already mentioned in the original description of Anthogorgia bocki (AURIvILLIUS, 1931), numerous abnormal outgrowths of the bark between the polyps are usually met with in all specimens of this gorgonacean clothed with bark. The tip of these outgrowths projects in a tubular form over the general surface of the bark, not exceeding the height of polypal verrucae and is usually bent slightly. They are all covered irregularly with fusiform spicules, smaller than those on the normal bark, and open at the end. These tube-like swellings or flaps are inhabited each by a small commensal polychaete referable to the genus Haplosyllis (sometimes treated as a subgenus of Syllis).

Syntypes: Many males and females from Seto, together with a part of their host gorgonacean Anthogorgia bocki (S. M. B. L., Type 161).

Description. Full-grown complete worm measures about $3 \mathrm{~mm}$ long and 0.18-0.24 mm wide for 38-42 setigerous segments. Body transparent, light orange, and flattened dorsoventrally in the anterior portion. Prostomium broader than long, with 2 pairs of small eyes. Median tentacle the longest, about $0.26 \mathrm{~mm}$ for 15 segments, more than four times the length of head. Lateral tentacles about half as long as median tentacle and 10-segmented. Palpi separate, though in close contact at base, not long. Dorsal peristomial tentacle about $0.5 \mathrm{~mm}$ long, longer than median tentacle and twice as long as ventral peristomial one.

Dorsal cirri on the anterior 1 st to 6 th segments are very elongate, multi-annulated; those on the succeeding 3 or 4 segments are shorter with $2-5$ annulations. Of these the 1st cirri are the longest, of about 22-33 annulations and the following cirri are alternate in length, as shown in one example:

\begin{tabular}{|c|c|c|c|c|c|c|c|c|c|c|c|}
\hline Body segment & 1st & 2nd & $3 \mathrm{rd}$ & 4 th & 5 th & 6 th & 7 th & 8 th & 9 th & 10th & 11th $\rightarrow$ \\
\hline $\begin{array}{l}\text { Number of annulations } \\
\text { in dorsal cirri }\end{array}$ & 33 & 7 & 7 & 15 & 6 & 10 & 5 & 3 & 3 & $3-1$ & $1 \cdots \cdots 1$ \\
\hline
\end{tabular}


The remainder gradually diminish in size posteriorly and not annulated. Ventral cirri very minute all throughout, not extending beyond the end of parapodia. Each parapodium supported internally by a simple aciculum which is hooked at end ; below

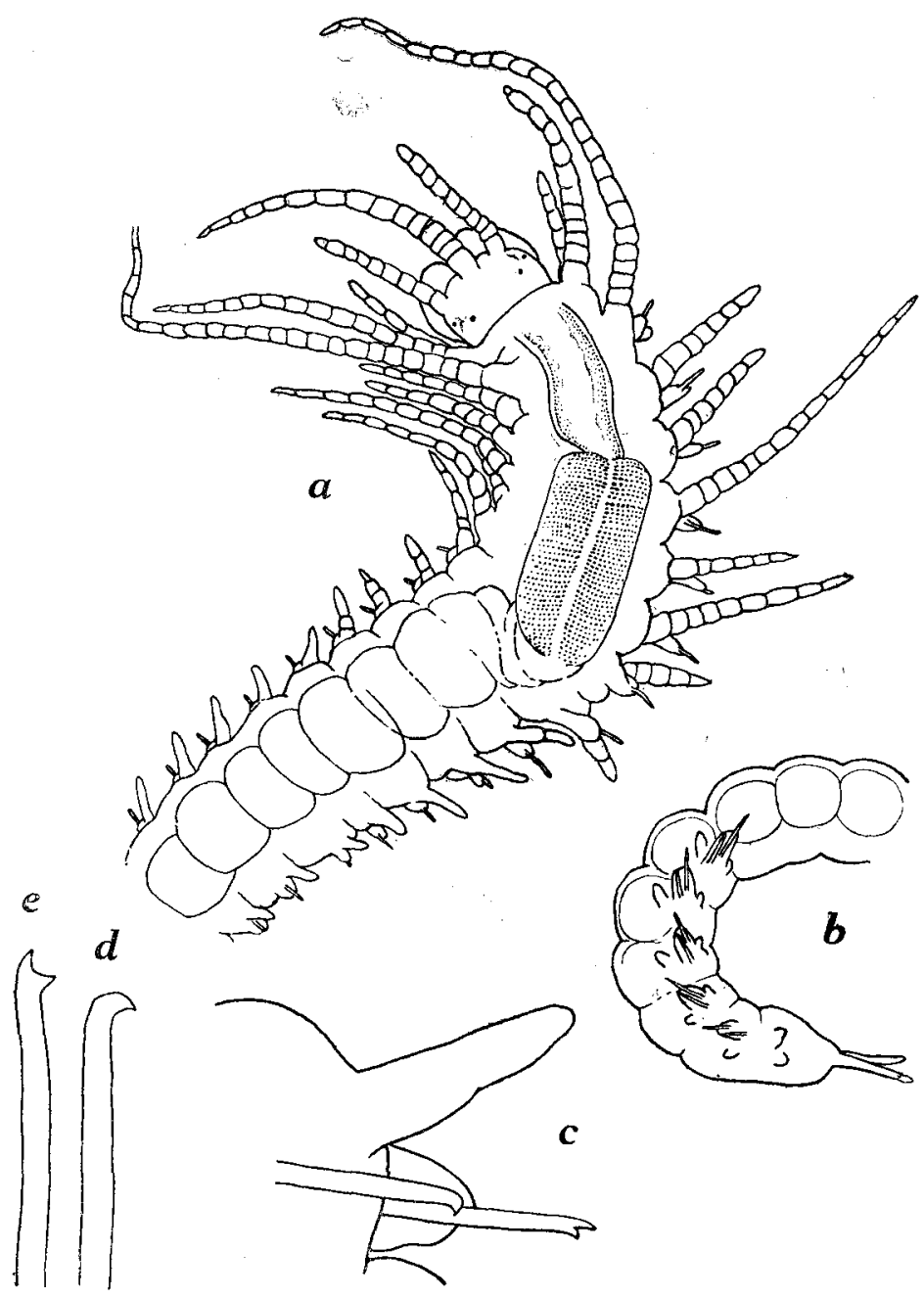

Fig. 2. Haplosyllis anthogorgicola sp. nov.

$a$, Anterior part of body, $\times 70 ; b$, posterior part, $\times 70 ; c$, parapodium, $\times 335 ; d$, aciculum, $\times 510 ; e$, seta, $\times 510$.

there is on the outside only one simple seta with bidentate tip. Pygidium with 2 relatively long anal cirri.

In the fresh state, the alimentary tract is visible even through the body wall. Pharynx is thin-walled, about $0.33 \mathrm{~mm}$ long, runs through only three segments and 
the next proventriculus of an enormous size, with strongly muscular walls, is approximately of the same length, extending through about four succeeding segments and $0.15 \mathrm{~mm}$ in diameter. It continues posteriorly to the annulated intestine of purplish orange color, running through the posterior segments, each bearing only a simple dorsal cirrus.

Remarks. This commensal syllid undoubtedly belongs to the genus (or subgenus of Syllis) Haplosyllis and is allied to the worldwide well-known Haplosyllis spongicola (GRUBE), living in association with sponges (FAUVEL, 1923, 1934). But it is distinctly different from the latter in the reduction of acicula and setae in the parapodia and the feeble development of dorsal cirri in the posterior setigerous segments. Such degeneration in structure is probably due to the permanent occurrence in tunnels or cavities formed beneath the bark of the gorgonacean. In other species of the genus Anthogorgia, we do not know still such a case of commensalism.

In connexion with this, it is to be noted that HICKSON (1940), in describing a muriceid gorgonacean Versluysia ramosa (THOMSON \& HENDERSON) from the Indian Ocean, recorded the occurrence of Syllis (Haplosyllis) spongicola in association with a specimen taken from off Cape Guardafui, 37 meters. Although it is impossible to decide if the Indian "Haplosyllis spongicola" found on Versluysia ramosa is the same as this $H$. anthogorgicola, it is probably not the true $H$. spongicola living only in sponges.

\section{Acknowledgment}

In closing I must express my gratitude to Ass'nt. Prof. H. Tsukahara, of the Amakusa Marine Biological Station for the laboratory facilities during my stay and for the loan of a photograph reproduced in P1. XXVII, fig. 1, and to Mr. K. MorIKAwA of the Ehime University for supplying me the collection of gorgonaceans.

\section{LITERATURE}

AurivilluUs, M. 1931. The gorgonaceans from Dr. S. Bock's Expedition to Japan and Bonin Islands 1914. Kungl. Svenska Vetensk. Akad. Handl., Ser. III, 9 (4) : 1-337, 6 pls.

BAYER, F. M. 1951. A revision of the nomenclature of the Gorgonidae (Coelenterata: Octocorallia), with an illustrated key to the genera. Journ. Wash. Acad. Sci., 41 (3): 91-102.

Fauvel, P. 1923. Polychètes errantes. Faune de France, 5: 1-488. Paris.

1934. Sur quelques syllidiens du Japon. Annot. Zool. Japon, 14 (3) : 301-315.

GoRdon, Is. 1926. Notes on a number of muriceid genera (Alcyonaria, Gorgonaceae), with special reference to spiculation. Proc. Zool. Soc. London, 1926 (2) : 509-531, pl. 1.

HrCKsoN, S. J. 1930. On the classification of the Alcyonaria. Ibid., 1930: 229-252.

1940. The Gorgonacea, with notes on two species of Pennatulacea. John Murray Exped., Sci. Rep., 6 (7): 267-317, pl. 1.

Kükenthal, W. 1924. Gorgonaria. Das Tierreich, Lief. 47 : xxviii +478 pp. Berlin u. Leipzig. und Gorzawsky, H. 1908. Japanische Gorgoniden. I Teil: Die Familien der

Primnoiden, Muriceiden und Acanthogorgiiden. (Beitr. zur Naturg. Ostasiens, Herausgegeb. 
von Dr. F. Doflein.) Abh. math.-phys. Kl. K. Bayer. Akad. Wiss., I Suppl. Bd., Abh. 3 : 1-71, 4 pls.

Nutting, C. C. 1910. The Gorgonacea of the Siboga Expedition, III. The Muriceidae. Siboga Exped., Mono. 13b, Livr. 47, 108 pp., 22 pls. Leiden.

StIAsNy, G. 1940. Grorgonaria aus dem Roten Meere. Sammlung Dr. Cyril Crossland, Ghardaqa, und der "Mabahith" Expedition 1934-5. Publ. Mar. Biol. Stat. Ghardaqa (Red Sea), 2 : 121-192, pls. $1-10$.

1943. Die Gorgonarien-Familie Acanthogorgiidae Kükenth. \& Gorz. mit besonderer Berücksichtigung des Materials der Siboga-Expedition. Zool. Anz., 141 (5/6) : 127-133.

1947. De Gorgonarien-Familie Acanthogorgiidae Kükenth. \& Gorz. (Met bijzondere inachtneming van het materiaal der Siboga-Expeditie). Verh. Konin. Nederl. Akad. Wet., Afd. Natuurk., II, 43 (2): 1-93, pls. 1-3.

STUDER, Th. 1889. Supplementary report on the Alcyonaria collected by H. M.S. Challenger. Challenger Reports, Zool. 32 (81) : 1-31, pls. 1-6.

Thomson, J. A. and DeAN, L. M. I. 1931. The Alcyonacea of the Siboga Expedition, with an addendum to the Gorgonacea. Siboga Exped., Mono. 13d, Livr. 115, 227 pp., 28 pls. Leiden. and HENDERSON, W. D. 1906. An account of the alcyonarians collected by the Royal Indian Marine Survey Ship “Investigator" in the Indian Ocean. I, The alcyonarians of the deep sea. xvi+132 pp., 10 pls. Calcutta.

and Simpson, J. J. 1909. Alcyonaria of the "Investigator." II, The Alcyonaria of the littoral area. $x i i+319$ pp., 9 pls. Calcutta.

VERRILL, A. E. 1868. Critical remarks on the halcyonoid polyps in the Museum of Yale College, with descriptions of new genera. Amer. Jour. Sci. and Arts, II, 45: 411-415.

1869. Synopsis of the polyps and corals of the North Pacific Exploring Expedition, etc. Additions and corrections. Proc. Essex Inst., 6: 41-48.

\section{EXPLANATION OF PLATE XXVII}

Fig. 1. Dry specimen of Anthogorgia bocki Aurivillius from Tomioka (courtesy Mr. H. Tsukahara).

$\times 1 / 6$.

Fig. 2. Dry specimen of Anthogorgia bocki Aurivillius from Seto.

$\times 1 / 9$.

$\times 1 / 3$.

Fig. 3. Specimen wholly covered with bark from Kii-ôsima.

Fig. 4. Part of branches of a living specimen from Seto, slightly magnified. $\times 5 / 3$. 
Publ. Seto Mar. Biol. Lab., V, 2 (1956)

PLATE XXVII

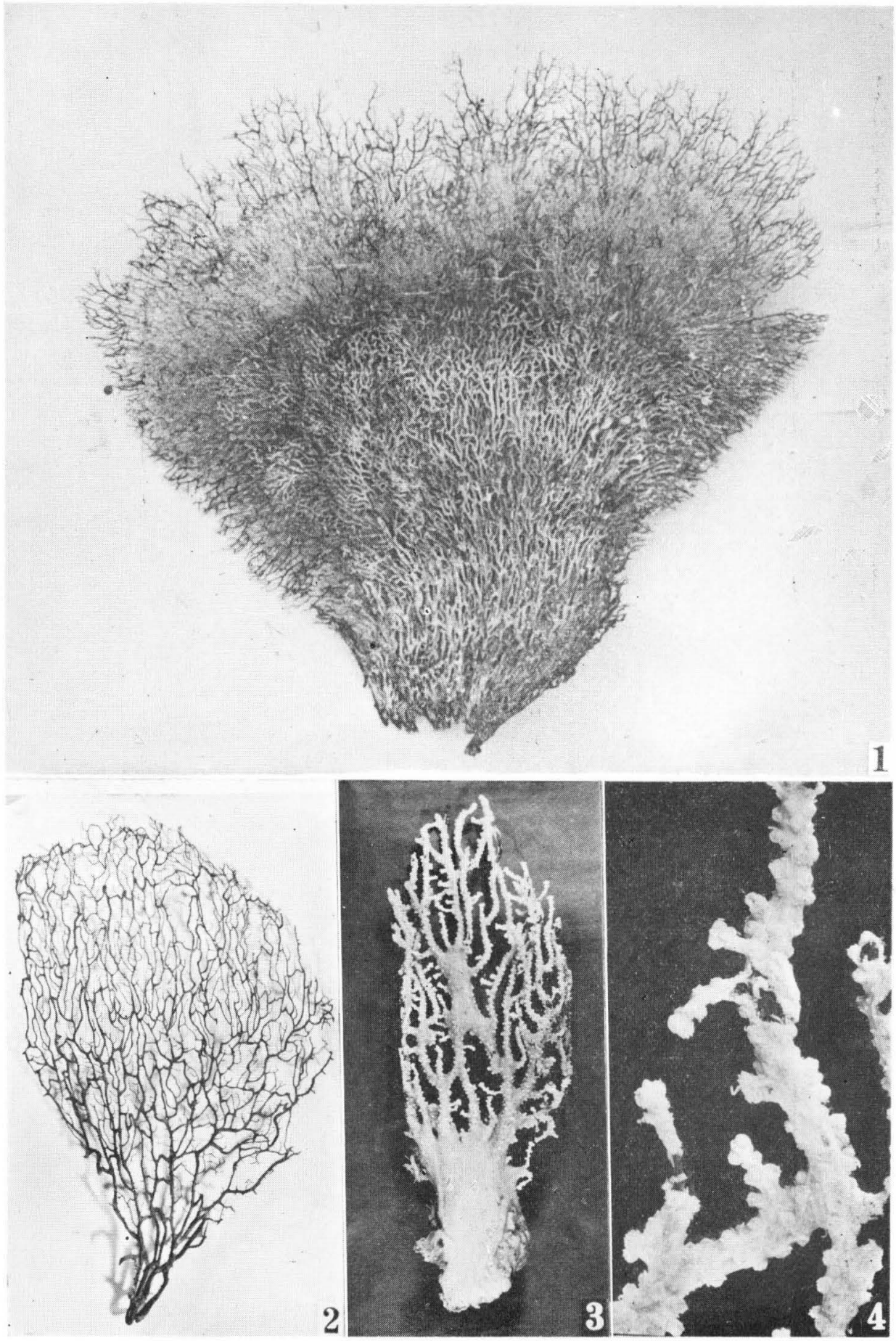

H. Utinomi : On the So-Called "Umi-utiwa." 